Jurnal Ilmiah Edunomika - Vol. 05, No. 01 (Februari 2021)

\title{
TRANSFORMASI PPSDM APARATUR PERHUBUNGAN MENUJU CORPORATE UNIVERSITY
}

\author{
Nelson Barus \\ Widyaiswara Ahli Utama, Kementerian Perhubungan Republik Indonesia \\ E-mail: nelsonkarokaro@gmail.com
}

\begin{abstract}
The changes of global conditions and the development of industrial revolution 4.0 are occurring at a very fast rate and in such a complex way, thus impacting on many resources in the transfortation sector hare to be able to anticipate this change, especially civil service (ASN) is required to be more adaptive, agile and professionall. PPSDMAP as a learning and training institution needs to perform corrections and service improrements in order to achleve the organitation's vision and mission. In the future, PPSDMAP should function not only as a training center, nor as a tactical body to fill competency gaps, but it needs to be upgraded to become a strategic business center for develoving competent civil service and encourasing to optimize their potentials through Continuons Learning and Learning Organization. This studi is carried out in PPSDMAP and addressing the issue of whether PPSDMAP has the potential to become a learning organization and Corporate University, along with the challenges and abstracts that are present. The instrument used in this study is questionnaire rejarding Learning Organization profile which was developed M. Marquardt in his book "Building The Learning Organization". This study encludes that PPSDMAP has the potential to become a Corporate University throught hard work and story commitment from all staker holders, particularly the leaders of PPSDMAP
\end{abstract}

Keywords : Corporate University; Learning Organization

\section{PENDAHULUAN}

Perubahan kondisi global dan berkembangnya revolusi industri 4.0 telah mengubah cara dalam bisnis, pemerintahan, dan pendidikan. Teknologi informasi dan transformasi digital menjadi platform agar semua lini bergerak lebih cepat, lebih efektif, lebih efisien, dan lebih berkualitas. Organisasi Kementerian Perhubungan dituntut dapat fokus dan mampu menyelesaikan masalah strategis organisasi dan peningkatan kinerja. Untuk mencapai hal tersebut, tentu diperlukan SDM yang berkualitas tinggi dan unggul. (Balitbangkumham, 2019)

Sesuai PP No. 17 Tahun 2020 tentang Manajemen PNS, Aparatur Sipil Negara harus memenuhi tiga kompetensi, yaitu Managerial, sosio kultural dan teknis. Selama ini pelatihan PNS difokuskan pada pelatihan dasar dan pelatihan kepemimpinan (Diklat Pirn) padahal PNS juga mempunyai hak 20 jam pelajaran dalam satu tahun untuk pengembangan kompetensinya.

Dalam era disruptif dan perkembangan teknologi yang begitu cepat dan tuntutan masyarakat yang semakin kompleks, Kementerian Perhubungan yang bertanggung jawab sebagai regulator di bidang transportasi harus dapat merespons perubahan tersebut. Setiap perubahan akan diikuti dengan tuntutan yang baru dari organisasi dan organisasi yang mampu merespons tuntutan tersebut akan jadi pemenang dalam persaingan ((Ayuningtias et al., 2016);(Keuangan et al., 2016)). Kementerian Perhubungan diminta untuk merespons dan 
mengimplementasikan aturan, strategi, dan kebijakan yang baru dan selalu membutuhkan prioritas.

Aparatur Sipil Negara (ASN) sebagai sumber daya manusia merupakan elemen yang utama dalam organisasi Kementerian Perhubungan dalam membuat regulasi dan memberikan pelayanan publik apabila dibandingkan dengan teknologi dan modal.

Dalam peningkatan kemampuan ASN agar dapat bekerja secara efisien dan efektif dalam upaya peningkatan kinerjanya, selama ini hanya diarahkan untuk mengikuti Diklat. Padahal, diperlukan peningkatan kompetensi dan penyegaran dalam organisasi di tempat ASN tersebut bekerja dan melakukan peningkatan pelatihan berbasis Human Capital Management melalui pengembangan ASN Corporate University. (Lembaga Administrasi Negara, 2018) Skema pelatihan ini memfungsikan selama unit kerja yang ada sebagai entitas pembelajaran dengan mengkombinasikan berbagai sistem pelatihan seperti E-learning Conveling, mentoring dengan on the job training (Publikasi LAN RI, 2018).

PPSDMAP sebagai entitas yang melaksanakan fungsi Pendidikan dan pelatihan harus lebih luas dari hanya menjadi pusat pelatihan (training center). PPSDMAP tidak lagi sekedar bersifat taktikal untuk memenuhi kesenjangan kompetensi (competence gap),namun harus diperluas menjadi strategic business center untuk dapat membentuk SDM Aparatur yang berpengetahuan serta terus mendorong mereka mengoptimalkan potensi yang dimilikinya melalui continuous learning.

Keberadaan PPSDMAP yang fungsinya melakukan Diklat yang selama ini dilakukan secara konvensional dipandang diperlukan suatu transformasi menuju corporate university. Untuk mencapai tujuan tersebut, salah satu pilihan yang dapat dilakukan PPSDMAP adalah melakukan transformasi kelembagaan menuju/menjadi corporate university.

\section{Permasalahan}

Pusat Pengembangan Sumber Daya Manusia Aparatur Perhubungan (PPSDM) mempunyai tugas melaksanakan pendidikan dan mengacu tugas dan fungsi PPSDMAP serta meningkatnya tuntutan dan kebutuhan masyarakat terhadap layanan jasa transportasi, Kementerian Perhubungan diharapkan mempunyai karaktersstik baik secara individu sebagai ASN maupun secara organisasi yang mempunyai kinerja tinggi dan pelaksanaan tugas.

Pendidikan dan pelatihan model konvensional bukan merupakan hal yang relevan lagi di era disruptif dalam upaya meningkatkan kompetensi SDM Aparatur Perhubungan.

Inovasi menuju corporate university merupakan suatu langkah yang strategic dan visioner, di mana di dalamnya terkandung imajinasi dan motivasi yang kuat untuk melakukan suatu transformasi dari kondisi saat ini PPSDMAP sebagai pusat pelatihan menuju entitas corporate university. Permasalahan yang ada di PPSDMAP belum optimalnya pemberdayaan SDM, belum adanya pengelolaan pengetahuan yang terstruktur, pembelajaran/pelatihan yang klasikal dan penerapan teknologi informasi/digital yang terbatas.

Permasaiahan yang ingin diteliti dalam karya tulis ini adalah :

a. Bagaimana potensi PPSDMAP sebagai entitas pendidikan dan pelatihan ditinjau dari dinamika pembelajaran, transformasi organisasi, pemberdayaan SDM, pengelolaan pengetahuan dan penerapan teknologi

b. Apa tantangan dan kendala penerapan corporate university pada PPSDMAP ?

\section{METODE PENELITIAN}

Metode penelitian yang dilakukan adalah deskriptif dan menggunakan kajian literatur serta kerangka penelitian secara logis. Kajian literatur dilakukan dengan mengkaji literatur mengenai 
corporate university dan mendalami aturan organisasi corporate university di lingkungan Kementerian Keuangan dan Kementerian Hukum dan HAM di mana lembaga diklatnya telah bertransformasi menjadi corporateuniversity.

\section{HASIL DAN PEMBAHASAN}

\subsection{Deskripsi dan Analisis Hasil Penelitian}

PPSDMAP sebagai institusi yang menangani kompetensi manajerial SDM Aparatur Perhubungan dalam rangka menuju organisasi pembelajar, maka dilakukan survey berupa pemberian kuesioner kepada para pejabat administrator, pejabat pengawas dan para widyaiswara di lingkungan PPSDMAP. Kuesioner yang diminta diisi meliputi dinamika pembelajaran, transformasi organisasi, pemberdayaan SDM, pengelolaan pengetahuan dan penerapan teknologi.

Kuesioner berisi sepuluh pernyataan dan diberikan pilihan dari empat jawaban yaitu sebagian kecil terlaksana (skala 1); sebagian terlaksana/sedang (skala 2); sebagian besar terlaksana (skala 3) dan sepenuhnya terlaksana (skala 4). Materi pernyataan untuk mendukung terbangunnya organisasi pembelajar dapat dilihat dari masing-masing subsistem sebagai berikut:

a. Subsistem dinamika pembelajar dilihat dari individual learning dan team learning.

b. Subsistem transformasi organisasi terkait dengan visi, budaya dan struktur organisasi.

c. Subsistem pemberdayaan sumber daya manusia ditinjau dari employee empowerment, leader emporwerment, public empowerment dan partnership empowerment.

d. Subsistem pengelolaan pengetahuan dilihat dari knowledge acquisition, knowledge creation, knowledge storage, dan knowledge transfer.

e. Subsistem penerapan teknologi mencakup sistem informasi pengetahuan, pembelajaran berbasis teknologi dan sistem elektronikal berbasis kinerja.

Dari data yang diperoleh melalui penyebaran kuesioner dihitung dan dianalisis data untuk mengetahui persepsi pegawai terhadap subsistem pembelajaran melalui pembagian nilai masingmasing skala dengan total skala.

Selanjutnya mengetahui nilai rata-rata subsistem pembelajaran di pergunakan rumus perhitungan Marquardt :

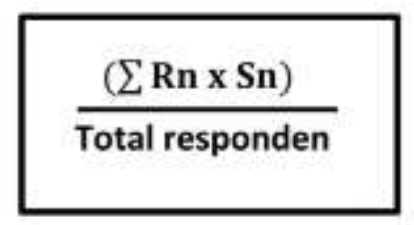

Keterangan :

$\mathrm{Rn} \quad=$ banyaknya responden tiap skala ke-n

$\mathrm{Sn} \quad=$ nilai skala ke-n

$\mathrm{n} \quad=$ skala $1,2,3$ da $\mathrm{n} 4$

Setelah nilai rata-rata subsistem maupun keseluruhan sistem learning organization diperoleh, kemudian dimasukkan ke dalam range-result oleh Marquardt untuk mengetahui nilai akhir tingkat kesiapan pembangunan learning organization. Berdasarkan range result Marquardt, apabila rata-rata nilai yang diperoleh 10-17 berarti buruk (poor), nilai 18-24 berarti cukup (fair), nilai 25- 32 berarti baik (good), sedangkan nilai 33-40 berarti sangat baik (excellent). Dari perolehan nilai rata-rata keseluruhan kemudian dideskripsikan berdasarkan lima subsistem dalam learning organization Marquardt yaitu dinamika pembelajaran (learning), transformasi organisasi (organization), pemberdayaan sumber daya manusia (people), 
pengelolaan pengetahuan (knowledge), penerapan teknologi (technology). Berikut uraian perhitungan subsistem dinamika pembelajaran sesuai hasil survey.

\subsubsection{Dinamika Pembelajaran}

Dinamika pembelajaran menurut Michael Marquardt dalam konsep Learning Organization merupakan subsistem sentral dalam sistem organisasi pembelajar. (Marquardt, 2002) Subsistem dinamika pembelajaran meresap ke dalam keempat subsistem lainnya (organization, people, knowledge, dan technology). Menurut Marquardt subsystem pembelajaran tidak dapat berdiri sendiri tanpa dukungan keempat subsistem lainnya, mereka saling melengkapi dan terkait secara dinamis. (Marquardt et al., 1994)

Subsistem organization, people, knowledge, dan technology diperlukan untuk meningkatkan dan memperluas kualitas dan pengaruh dari learning, yang pada gilirannya menembus ke subsistem lainnya. Sehingga, apabila salah satu subsistem tersebut tidak ada atau lemah, maka secara signifikan akan berpengaruh pada efektivitas subsistem lainnya.

Subsistem dinamika pembelajaran yang terjadi di PPSDMAP secara keseluruhan masih menghadapi berbagai kendala guna mendukung proses pembelajaran yang berkelanjutan sebagai ciri dari organisasi pembelajar. Dimensi pertama pada subsistem dinamika pembelajaran (learning) yaitu tingkatan pembelajaran. Pada level pembelajaran individu belum dapat dilakukan sepenuhnya secara efektif, misal pelaksanaan pembelajaran belum sepenuhnya memberikan kesempatan kepada seluruh level pegawai.

Secara substantif program pembelajaran yang ada belum sepenuhnya mengarah pada kebutuhan seluruh unit guna mencapai tujuan strategis organisasi. (Allen, 2002) Pada dimensi kedua berkaitan dengan tipe pembelajaran, Secara umum, tipe pembelajaran yang terjadi menggunakan dua pendekatan, yaitu pertama pembelajaran atas dasar refleksi kebutuhan organisasi saat ini dan pada waktu bersamaan menerapkan pengetahuan tersebut sebagai upaya pengembangan individu, kelompok dan organisasi (pembelajaran tindakan action learning), kedua, pembelajaran atas permasalahan-permasalahan yang dihadapi pada masa lalu kemudian dilakukan inovasi ataupun modifikasi kegiatan/tindakan yang dilakukan untuk menghilangkan permasalahan yang kerap terjadi di dalam organisasi. Dimensi ketiga, dalam hal keterampilan (skills) pembelajaran. Secara umum, penerapan dimensi keterampilan (skills) yang terjadi di PPSDMAP masih sangat kurang sehingga perlunya upaya perbaikan serta penguatan. Gambaran kuantitatif mengenai subsistem dinamika pembelajaran (learning dynamics) di PPSDMAP diperoleh melalui survey persepsi pegawai pada gambar 1 dan tabel 1

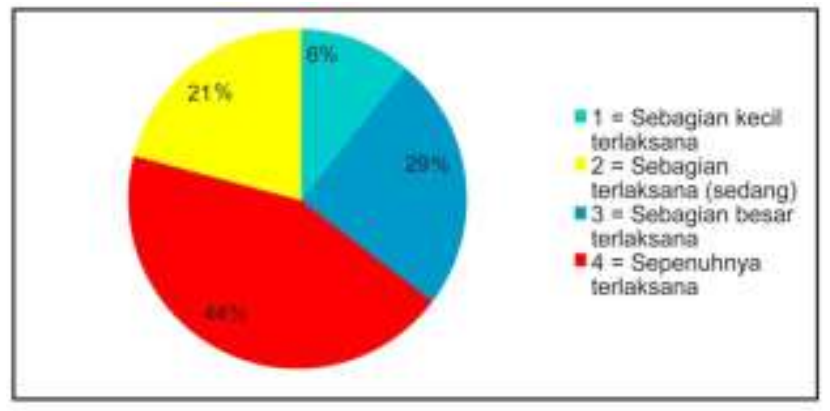

Gambar1

Data Persepsi Pegawai Penerapan Subsistem Dinamika Pembelajaran

Hasil survey menggambarkan bahwa $44 \%$ responden menyatakan bahwa penerapan dinamika pembelajaran sebagian besar terlaksana. 
Tabel 1.

Nilai Rata-Rata subsistem dinamika pembelajaran

\begin{tabular}{|c|c|c|c|c|c|}
\hline Nilai Rata-Rata & 1 & 2 & 3 & 4 & Jumlah \\
\hline X.1 & 18 & 176 & 393 & 252 & 839 \\
\hline Mean & 0,6 & 5,87 & 13,1 & 8,4 & $\mathbf{2 7 , 9 7}$ \\
\hline
\end{tabular}

Data yang diperoleh dari penilaian pegawai, nilai rata -rata penerapan subsistem dinamika pembelajaran (range result) yaitu 27,97. Menurut range result Marquardt masuk pada kategori baik $(25-32=$ good $)$.

Berdasarkan perhitungan tersebut perlu dilakukan upaya perbaikan ataupun peningkatan khususnya pada elemen-elemen yang menjadi titik lemah penerapan subsistem dinamika pembelajaran. Misalnya, pembelajaran berkelanjutan oleh seluruh pegawai PPSDMAP serta penerapan metodologi yang mempercepat proses pembelajaran. Hal ini dapat terlihat pada kondisi empiris pembelajaran yang terjadi di PPSDMAP belum dapat dirasakan oleh seluruh pegawai. Materi pembelajaran belum sepenuhnya mendukung kebutuhan kompetensi seluruh unit organisasi di PPSDMAP hanya sebagian materi pembelajaran dapat diterapkan pegawai dalam mendukung pelaksanaan tugas dan penyelesaian pekerjaannya.

\subsubsection{Transformasi Organisasi}

Transformasi, suatu organisasi harus memiliki visi bersama (shared vision) sebagai fondasi yang rnelatarbelakangi perubahan cara pandang dari organisasi konvensional menjadi organisasi pembelajar. Selain visi, suatu organisasi tentu memiliki cara pandang dan cara kerja beragam yang terwujud melalui identitas dan nilai (values) hingga akhirnya membentuk budaya tersendiri (learning culture, non-learning culture, hingga anti-learning culture). Nilai-nilai tersebut, menurut Marquardt,(Marquardt, 2002) "complement the pulling force of an organization's vision by pushing the company to reach that vision" yang menempatkan budaya organisasi menjadi hal krusial untuk ditransformasikan. Selanjutnya dibutuhkan strategi yang tepat dan struktur organisasi yang mendukung untuk dapat mendorong transformasi organisasi secara keseluruhan. PPSDMAP sebagai instansi di sektor pemerintahan, memiliki karakteristik budaya organisasi birokratis, yang dapat dilihat dari sifat yang tidak fleksibel, peraturan yang rigid, tingginya sentralisasi, dan gaya kepemimpinan yang afirmatif. (Citrawan et al., 2019)

Struktur organisasi sebagai dimensi selanjutnya, memegang peranan penting khususnya dalam hal pengawasan kinerja, alur komunikasi, pengambilan keputusan, dan kontrol internal dalam organisasi (Sugiarsono et al., n.d.). Kondisi struktur organisasi yang ideal menurut Marquardt adalah struktur yang menunjukkan flexibility, openness, freedom, and opportunity, Namun, data lapangan menunjukkan bahwa masih terdapat permasalahan terkait struktur organisasi di lingkungan PPSDMAP khususnya terkait dengan pembinaan jabatan fungsional widyaiswara.

Keselarasan visi, pergeseran budaya organisasi, restrukturisasi, hingga strategi yang tepat, tetap memerlukan komitmen dari pimpinan tertinggi organisasi untuk menentukan arah kebijakan, khususnya terkait transformasi organisasi. PPSDMAP sebagai institusi menuju organisasi pembelajar dapat digambarkan melalui kondisi existing dari dimensi dalam subsistem transformasi organisasi. Namun, ketiga dimensi tersebut perlu dipahami sebagai sebuah siklus yang saling terkait antara satu dimensi dengan dimensi lainnya. Pertama, dalam hal visi, masih belum terdapat keselarasan antara visi strategis organisasi dengan visi pribadi masing-masing 
pegawai, perbedaan visi tersebut terlihat jelas khususnya pada jabatan fungsional tertentu, mengingat jabatan fungsional tertentu memiliki kewajiban untuk memenuhi standar kinerja, yang dalam beberapa kasus, tidak secara langsung bersinggungan dengan tugas dan fungsi utama dari organisasi. Kedua, dalam dimensi budaya organisasi, PPSDMAP sebagai instansi pemerintahan masih memiliki karakter budaya birokratis, sehingga belum tercipta learning culture yang dapat membangun atmosfer pembelajaran di dalam organisasi. Tata Nilai sebagai values yang dimiliki oleh organisasi, masih belum mampu menggeser budaya kerja birokratis yang ada di PPSDMAP. Ketiga, secara struktur, masih terdapat permasalahan egosektoral baik ditingkat individu maupun pada bidang/bagian dan jabatan fungsional. Pimpinan memegang peranan penting dalam melakukan transformasi organisasi di lingkungan PPSDMAP.

Berikut pada gambar2 dapat dilihat data persepsi pegawai PPSDMAP pada subsistem Transformasi Organisasi

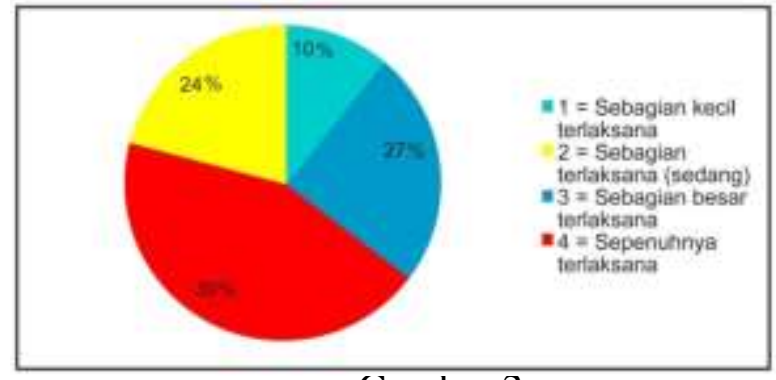

Gambar 2

Data Persepsi Pegawai Penerapan Subsistem Transformasi Organisasi

Gambaran kuantitatif atas subsistem transformasi/organisasi (transformation organization) menunjukkan $39 \%$ responden memiliki persepsi bahwa penerapan transformasi organisasi di PPSDMAP sebagian besar telah terlaksana. Sebagaimana dapat dilihat pada gambar 2.

Tabel 2

Nilai Rata-Rata Subsistem Transformasi Organisasi

\begin{tabular}{|c|c|c|c|c|c|}
\hline Nilai Rata-Rata & 1 & 2 & 3 & 4 & Jumlah \\
\hline X.1 & 31 & 164 & 348 & 284 & 827 \\
\hline Mean & 1,03 & 5,47 & 11,60 & 9,47 & $\mathbf{2 7 , 5 7}$ \\
\hline
\end{tabular}

Secara keseluruhan, nilai rata-rata penerapan subsistem transformasi organisasi (organization) dalam mendukung kesiapan pembangunan learning organization di PPSDMAP diperoleh nilai rata-rata 27,57\%. Hal ini dapat diartikan bahwa penerapan subsistem transformasi organisasi masih masuk pada kategori baik menurut range result Marquardt $(25-32=$ good $)$.

Dari uraian perhitungan di atas, dapat diketahui beberapa elemen yang masih lemah, Misalnya, dalam dimensi visi, meskipun secara keseluruhan tingkat kesiapan dimensi ini memperoleh nilai sebesar $34 \%$ pada skala 2 dan 3 akan tetapi masih terbatas pada dukungan pimpinan terhadap transformasi visi dari sebuah organisasi pembelajar di PPSDMAP. Dengan kata lain sebagian pegawai di PPSDMAP belum memiliki pemahaman akan pentingnya menjadi suatu organisasi pembelajar untuk mencapai visinya.

\subsubsection{Pemberdayaan Sumber Daya Manusia}

Pemberdayaan SDM dalam organisasi pembelajar dimaksudkan agar organisasi dapat memberdayakan (empowering) dan memampukan (enabling) seluruh komponen SDM yang ada, 
baik internal maupun eksternal. Dalam konteks di PPSDMAP, bentuk pemberdayaan yang dilakukan oleh pimpinan terhadap pegawai dilakukan melalui penugasan. Penugasan tersebut belum linear dengan kebijakan pengembangan kompetensi, idealnya ditentukan sesuai dengan merit system, yaitu kebijakan dan pengembangan SDM berdasarkan kualifikasi dan kompetensi yang dimiliki pegawai, meskipun dalam beberapa kasus, pimpinan mendelegasikan tugas karena faktor kepercayaan. Selain penugasan, pemberdayaan SDM juga dilakukan dengan menjalin kerja sama dengan pihak eksternal melalui penandatanganan memorandum ofunderstanding (MoU).

Persepsi pegawai PPSDMAP terkait penerapan subsistem pemberdayaan SDM tampak pada gambar 3

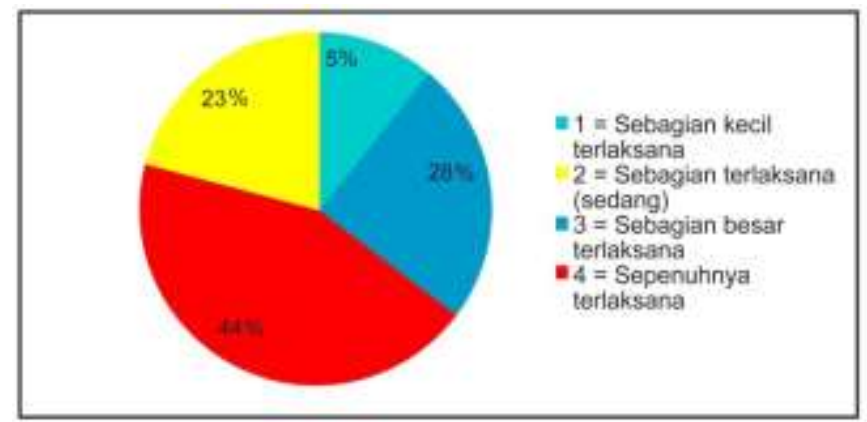

Gambar 3

Data Persepsi Pegawai Penerapan Subsistem Pemberdayaan SDM

Data kuantitatif mengenai penerapan subsistem pemberdayaan SDM (people) dilingkungan PPSDMAP, $44 \%$ responden memiliki persepsi bahwa pemberdayaan SDM di PPSDMAP sebagian besar telah terlaksana. Selanjutnya nilai rata-rata subsistem pemberdayaan SDM pada tabel 3

Tabel 3

Nilai Rata-Rata Subsistem Pemberdayaan SDM

\begin{tabular}{|c|c|c|c|c|c|}
\hline Nilai Rata-Rata & 1 & 2 & 3 & 4 & Jumlah \\
\hline X.1 & 15 & 168 & 396 & 276 & 855 \\
\hline Mean & 0,5 & 5,6 & 13,2 & 9,2 & $\mathbf{2 8 , 5}$ \\
\hline
\end{tabular}

Penghitungan nilai rata-rata keseluruhan penerapan subsistem pemberdayaan SDM dalam lingkungan PPSDMAP sebagai learning organization berada pada angka 28,5 sehingga dapat dipahami bahwa subsistem pemberdayaan SDM masuk dalam kategori baik menurut range result Marquardt $(25-32=$ good $)$.

Dari uraian perhitungan data di atas, pada dimensi pemberdayaan pegawai (employee empowerment) perlu penguatan khususnya terkait dengan pendelegasian tugas yang sesuai dengan tanggung jawab serta kemampuan pegawai. Hal tersebut perlu dilakukan agar terwujudnya keseimbangan beban kerja antar pegawai. Kemudian pada dimensi pemberdayaan pimpinan (leader empowerment), meskipun peran pimpinan dalam memberikan arahan, bimbingan ataupun menginisiasi kegiatan pemberdayaan SDM sudah dilaksanakan dan memiliki tingkat penerapan cukup kuat akan tetapi belum dibentuk dalam kegiatan atau program pengembangan SDM secara intensional. Selanjutnya untuk dimensi customer (masyarakat) dan partnership (mitra) masing-masing memperoleh nilai kesiapan $42 \%$ dan $43 \%$ berada pada skala 3. Artinya kedua dimensi tersebut cukup siap untuk membangun PPSDMAP sebagai learning organization menuju Corporate University. 


\subsubsection{Pengelolaan Penegetahuan}

Menurut Marquardt disebutkan bahwa "Suatu organisasi dapat memperoleh pengetahuan dari berbagai sumber, baik pengetahuan yang bersumber dari internal maupun eksternal organisasi, Pengetahuan yang bersumber dari internal organisasi dapat berupa pengetahuan tacit pegawai, pengalaman organisasi, dan implementasi dari proses perubahan. Sedangkan pengetahuan yang bersifat eksternal dapat diperoleh melalui kegiatan benchmarking, konferensi, jasa konsultan, hingga kolaborasi dan bermitra dengan organisasi lain."

Pengelolaan pengetahuan di lingkungan PPSDMAP diperoleh melalui persepsi dan pengalaman pegawai pada tiga level, yakni pimpinan, administrasi, dan fungsional. Dalam penelitian ini, data dipilah ke dalam dua perspektif, yakni sosial dan teknis. Perspektif sosial terbagi menjadi struktur, kultur, dan perorangan, sedangkan perspektif teknis menggambarkan bentuk penerapan teknologi. Pada sisi struktur, siklus pengelolaan pengetahuan di PPSDMAP cenderung terdesentralisasi di masing- masing unit kerja, baik di antara bidang dan bagian.

Berdasarkan hasil survey pada PPSDMAP, terdapat tiga hal yang masih memerlukan pembenahan, meliputi : (i) diperlukan upaya pengembangan, baik secara sistem maupun struktur agar seluruh pengetahuan yang dimiliki oleh organisasi tersusun dan tersimpan dengan baik sehingga dapat dimanfaatkan; (ii) peningkatan pemahaman akan pentingnya pembentukan tim lintas tugas jabatan, sebagai salah satu cara untuk. memaksimalkan pemindahan pengetahuan antar unit organisasi : dan (iii) diperlukan bentuk, strategi, ataupun mekanisme baru agar tercipta proses pemindahan pengetahuan yang berkelanjutan.

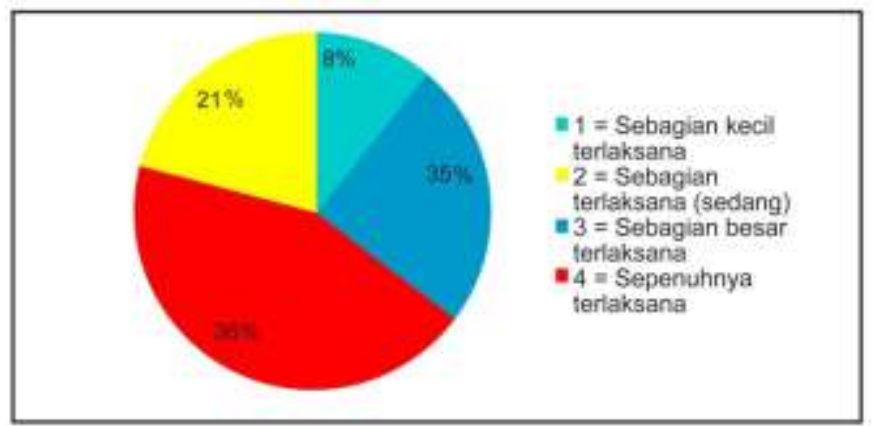

Gambar 4

Data Persepsi Pegawai Penerapan Subsistem Pengelolaan Pengetahuan

Berdasarkan data kuantitatif dan persepsi responden penerapan subsistem manajemen pengetahuan sebagian besar terlaksana sebesar $36 \%$.

Tabel 4

Nilai Rata-Rata Subsistem Pengelolaan Pengetahuan

\begin{tabular}{|c|c|c|c|c|c|}
\hline Nilai Rata-Rata & 1 & 2 & 3 & 4 & Jumlah \\
\hline X.1 & 26 & 210 & 321 & 248 & 805 \\
\hline Mean & 0,87 & 7,0 & 10,7 & 8,27 & $\mathbf{2 6 , 8 3}$ \\
\hline
\end{tabular}

Nilai rata -rata penerapan subsistem pengelolaan pengetahuan dalam mendukung kesiapan pembangunan learning organization di PPSDMAP sebesar 26,83\%. Artinya, penerapan subsistem ini masuk pada kategori baik menurut range result Marquardt $(25-32=$ good $)$ meskipun masih terdapat beberapa elemen yang menjadi kelemahan dalam mendukung penerapannya. Dari perhitungan data secara keseluruhan dimensi pada subsistem pengelolaan 
pengetahuan (knowledge acguisition, knowledge creation, knowledge storage, knowledge transfer and dissemination) memperoleh nilai tingkat kesiapan cukup untuk untuk mendukung pembangunan learning organization PPSDMAP menuju Corporate University. Untuk dimensi knowledge acquisition memperoleh tingkat kesiapan sebesar $37 \%$ berada pada skala 3 . Hal ini terkait upaya perolehan pengetahuan melalui pencarian informasi untuk meningkatkan kinerja organisasi dengan dukungan sistem yang dapat diakses untuk mengumpulkan informasi (internal dan eksternal) serta melihat perkembangan dan membandingkan best practices organisasi lain.

Pada dimensi knowledge creation memperoleh tingkat kesiapan sebesar $40 \%$ dan berada pada skala 3. Ini berarti pelaksanaan pelatihan pegawai untuk memiliki keterampilan berpikir kreatif, berinovasi dan bereksperimen serta uji coba dalam pengembangan pelayanan sudah mulai dilaksanakan. Pada dimensi knowledge storage sebesar 38\% dan berada pada skala 2. Hal ini berarti pengkodean dan penyimpanan serta pemberian kemudahan bagi yang membutuhkan pengetahuan masih lemah, sehingga diperlukan upaya pengembangan, baik secara sistem maupun struktur agar seluruh pengetahuan yang dimiliki organisasi tersusun dan tersimpan dengan baik sehingga dapat dimanfaatkan. Selanjutnya, pada dimensi knowledge transfer memperoleh tingkat kesiapan sebesar $36 \%$ berada pada skala 2 . Hal ini menunjukan pengembangan strategi dan mekanisme baru agar terciptanya transfer pengetahuan masih lemah.

Dorongan kuat kepada seluruh unsur organisasi untuk menghasilkan pengetahuan menjadi modal utama penerapan subsistem dinamika pembelajaran sehingga dapat mendukung pembangunan learning organization PPSDMAP menuju Corporate University.

\subsubsection{Penerapan Teknologi}

Penerapan teknologi dalam pengelolaan pengetahuan sudah dilaksanakan di lingkungan PPSDMAP dalam berbagai bentuk, walaupun belum optimal. Pembelajaran berbasis teknologi informasi sudah dilakukan PPSDMAP khusunya pada masa Pandemi Covid-19 tahun 2020, melalui pelatihan non klasikal dengan media e-leaming seperti Dikat Pim, Pelatihan Kepemimpinan Pengawas (PKP), Pelatihan Kepemimpinan Administrator (PKA) dan Pelatihan Kepemimpinan Nasional tingkat II (PKN II).

Pelatihan kepemimpinan melaluie-learning juga dilakukan pada pelatihan latihan dasar CPNS (Latsar), bimtek kepemimpinan transportasi dan komunikasi serta pelatihan Reform Leadership Training (RLT). Penerapan teknologi di lingkungan PPSDMAP telah diupayakan penggunaan teknologi dalam mengolah pengetahuan baik oleh bidang/bagian dan individu. PPSDMAP juga telah menerapkan teknologi untuk memperkaya pengetahuan belajar melalui kegiatan pembelajaran yang berbasis video dan disebarluaskan melalui kanal dilaman youtube, facebook dan atau instagram, walaupun masih terbatas.

Pelaksanaan pembelajaran dengan metode e-learning di PPSDMAP masih terdapat kekurangan dan ketidaksempurnaan. Kendala utama yang dihadapi dalam penerapan teknologi secara keseluruhan adalah kurangnya pemahaman mengenai teknologi dan informasi itu sendiri dan PPSDMAP belum mempunyai aplikasi Learning Management System (LMS). Dengan adanya aplikasi LMS diharapkan fungsi administrator, dokumentasi, pelacakan, pelaporan dan materi training dapat dilakukan, sehingga proses pembelajaran dapat disederhanakan dan terintegrasi.

Sesuai perhitungan data, tampak bahwa sistem informasi pengetahuan dan pembelajaran berbasis teknologi berada pada skala 3 dan 2, walaupun sudah ada kemudahan internet dan kemudahan merniliki akses rnemperoleh data yang dibutuhkan namun belum terbangun suatu sistem dalam pengelolaan pengetahuan secara masif dan memudahkan transfer pengetahuan kepada seluruh unit organisasi yang membutuhkan. 
Pada dimensi sistem elektronik berbasis kinerja terkait dengan dukungan terhadap proses pembelajaran guna meningkatkan kinerja pegawai telah terlaksana cukup baik, dominan berada pada skala 3.

Berdasarkan persepsi kauntitatif dari sepuluh indikator pengukuran subsistem penerapan teknologi sebagian besar persepsi pegawai telah terlaksana yaitu 39\% sebagaimana tercantum dalam gambar5.

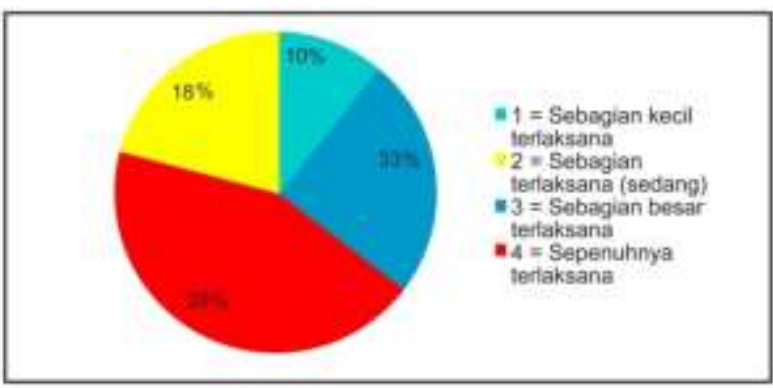

Gambar 3.5

Data Persepsi Pegawai Penerapan Subsistem Penerapan Teknologi

Tabel 5

Nilai Rata-Rata Subsistem Penerapan Teknologi

\begin{tabular}{|c|c|c|c|c|c|}
\hline Nilai Rata-Rata & 1 & 2 & 3 & 4 & Jumlah \\
\hline X.1 & 31 & 200 & 348 & 212 & 791 \\
\hline Mean & 1,03 & 6,67 & 11,6 & 7,07 & $\mathbf{2 6 , 3 7}$ \\
\hline
\end{tabular}

Secara keseluruhan perhitungan nilai rata-rata penerapan subsistem penerapan teknologi sudah cukup baik untuk mendukung kesiapan PPSDMAP membangun Learning Organization dalam rangka menuju Corporate University diperoleh nilai rata-rata 26,37\% menurut range result Marquardt penarapan subsistem ini masuk kategori baik $(25$ - 32 = good), meskipun penggunaan aplikasi Learning Management System (LMS) belum terlaksana dan ini menjadi elemen kelemahan dalam mendukung penerapan teknologi tersebut.

\subsection{Rekapitulasi Subsistem Organisasi Pembelajaran}

Tabel 6

Rekapitulasi Subsistem Organisasi Pembelajar

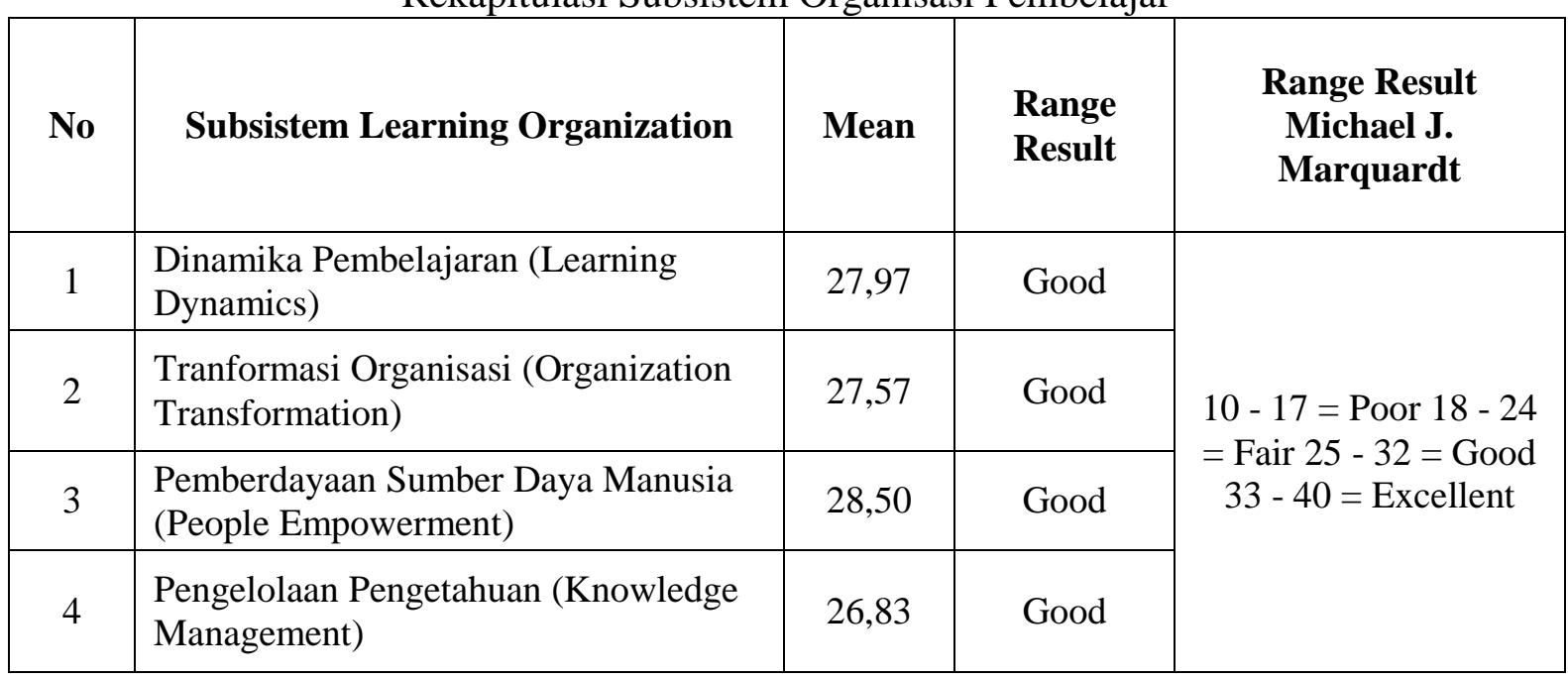




\begin{tabular}{|c|l|c|c|c|}
\hline 5 & $\begin{array}{l}\text { Penerapan Teknologi (Technology } \\
\text { Application) }\end{array}$ & 26,37 & Good & \\
\hline
\end{tabular}

Berdasarkan Tabel 3.6 nilai rata-rata tingkat kesiapan yang diperoleh setiap subsistem dalam mendukung pembangunan learning organization di PPSDMAP masuk dalam kategori baik. Hal ini mengindikasikan bahwa PPSDMAP mempunyai potensi menjadi organisasi pembelajar (learning organization) dan menuju Corporate University meskipun masih perlu dilakukan beberapa upaya perbaikan pada tiap subsistemnya.

\subsection{Analisis Strategi Membangun Learning Organization di PPSDMAP}

Dalam upaya mengetahui strategi Transformasi PPSDMAP menuju Corporate University, maka dilakukan wawancaraterhadap beberapa pejabat struktural dan widyaiswara di lingkungan PPSDMAP, diperoleh informasi/pendapat sebagai berikut:

- Terdapat pejabat yang optimis dengan hasil yang diperoleh dari penelitian ini dan yakin dapat terbangunnya organisasi pembelajaran (learning organization) secara bertahap di PPSDMAP.

- Beberapa pejabat agak ragu jika PPSDMAP dapat membangun dan menerapkan learning organization karena melihat fenomena masih belum adanya pemahaman dan komitmen atau persepsi yang sama tentang pentingnya penerapan learning organization, khususnya di level pejabat struktural sehingga masih ada anggota organisasi yang masih resisten terhadap perubahan dan belum sepenuhnya proses pembelajaran itu dihubungkan dalam proses kerja.Transformasi PPSDMAP menuju organisasi pembelajar masih banyak hal yang perlu diperbaiki dan ditingkatkan. Berdasarkan hasil analisis lima subsistem pembelajaran dan informasi/pendapat pejabat struktural dan widyaiswara dapat dianalisis strategi yang harus dilakukan guna membangun learning organization dan transformasi menuju Corporate University di PPSDMAP sebagai berikut:

1) Membangun komitmen terlebih dahulu dijajaran pejabat struktural untuk memberdayakan seluruh subsistem yang dimiliki oleh PPSDMAP (pembelajaran, organisasi, manusia, pengetahuan dan teknologi) yang disertai dengan kebijakan menuju organisasi pembelajar.

2) Perlu dikomunikasikan antar anggota organisasi (seluruh pegawai) tentang visi dari learning organization. Arah (direction)yang akan dituju oleh organisasi di masa mendatang (vision).

3) Menerapkan teknologi terbaik untuk the best learning, dengan cara meningkatkan kecanggihan teknologi informasi (information technology sophistication).

4) Melakukan improving dan learn continuously serta mentransformasi budaya organisasi pada sebuah continuous learning.

5) Pemimpin menjadi model dalam komitmen untuk belajar.

6) Memberdayakan dan mendorong pegawai untuk memperluas belajar pada tingkatan individu, kelompok dan organisasi.

Strategi yang dapat dilakukan untuk membangun learning organization untuk setiap subsistem yang dikemukakan oleh Marquardt terkait dengan kondisi yang ada di PPSDMAPadalah :

1) Membangun subsistem pembelajaran.

a. kemampuan berdialog dalam organisasi.

b. Mengembangkan Menciptakan program pengembangan karir.

c. Menciptakan program-program pengembangan pribadi. 
d. Meningkatkan kemampuan belajar kelompok.

e. Mendukung penerapan cara-cara berpikir sistem.

f. Mengubah model mental yang berguna bagi proses pembelajaran.

2) Membangun subsistem organisasi

a. Terus-menerus melihat ke masa depan guna mengembangkan visi organisasi pcmbelajar.

b. Komitmen dari para top-level-management yang mendukung pembentukan organisasi pembelajar dan proyek-proyek pembelajaran dalam organisasi.

c. Menciptakan iklim yang mendukung organisasi untuk terus menerus belajar.

d. Mengenali dan memberikan penghargaan bagi individu maupun kelompok yang telah 'belajar' .

e. Mendesain sedemikian rupa sehingga 'belajar' menjadi bagian integral dari semua kebijakan dan prosedur.

f. Menciptakan waktu, ruang dan lingkungan fisik yang mendukung pembelajaran.

3) Membangun subsistem sumber daya manusia

a. Mengintegrasikan pemberian penghargaan kepada para karyawan yang mau belajar ke dalam sistem personalia organisasi.

b. Memberdayakan karyawan untuk belajar dan menghasilkan (to learn and to produce).

c. Mendorong pimpinan uniuk membuat model serta proyek- proyek pembelajaran.

d. Menyeimbangkan kegiatan belajar dan kebutuhan pengembangan individu dan organisasi.

e. Menyediakan kesempatan untuk mengenyam pendidikan bagi komunitas masyarakat sekitar.

4) Membangun dan mengelola pengetahuan yang ada dalam organisasi

a. Mengorganisasikan kesempatan belajar untuk masing-masing anggota organisasi.

b. Mengembangkan cara-cara berpikir dan belajar yang kreatif dan generatif.

c. Melatih karyawan untuk secara sistematis menyimpan dan memakai informasi yang didapatnya.

d. Mendorong pencampuran anggota kelompok dan rotasi kerja untuk memaksimalkan pemindahan pengetahuan.

e. Mengembangkan pengetahuan yang berdasar pada nilai-nilai dan kebutuhan pembelajaran dalam organisasi.

f. Menciptakan mekanisme pengumpulan dan penyimpanan hasil belajar.

5) Penerapan teknologi

a. Mendorong semua karyawan untuk mendapat akses terhadap informasi.

b. Mengembangkan multimedia dan pusat belajar berbasis teknologi

c. Menggunakan teknologi untuk memperoleh pengetahuan dan ide-ide, baik dari dalam maupun dari luar organisasi.

d. Mengaplikasikan Learning Management System (LMS).

e. Membangun sistem pelatihan dan kemampuan berteknologi internal.

f. Mengembangkan kesadaran dan penghargaan terhadap teknologi sebagai suatu alat yang mempunyai kekuatan luar biasa untuk mengembangkan kemampuan pembelajaran di seluruh organisasi dan meningkatkan tanggung jawab kepedulian manajemen dan karyawan terhadap pentingnya aplikasi teknologi. 


\subsection{Tantangan Dan Kendala Penerapan Corporate University}

Berdasarkan hasil observasi dan wawancara dengan pejabat dan widyaiswara di lingkungan PPSDMAP diperoleh informasi yang menunjukan bahwa PPSDMAP memiliki tantangan dan kendala sebagai berikut

1) Pemanfaatan sumber daya pembelajaran belum efektif.

Pada PPSDMAP sumber daya pembelajaran belum dievaluasi tingkat efisiensi dan efektifitasnya seperti kualitas fisik, format konteks/isi, rancangan, biaya, perkembangan teknologi digital, telekomunikasi dan sistem informasi.

2) Pengukuran Efektifitas Proses Pembelajaran Belum Optimal

Pengukuran efektifitas proses pembelajaran pada PPSDMAP terkait waktu, biaya dan kualitas layanan pembelajaran telah dilakukan dan dapat diketahui progres keberhasilan setiap program namun belum memberikan feedback (tepat waktu dan valid) bagi pengambil keputusan untuk memberikan dukungan yang signifikan dan melakukan perbaikan strategi proses pembelajaran.

3) Dalam proses pengambilan keputusan tidak melibatkan seluruh pegawai atau individu dalam organisasi, akan tetapi pimpinan mengambil secara sepihak semua kebijakan dan peraturan tanpa mengakomodasi kepentingan dan menggali potensi yang dimiliki bawahan (hasil observasi).

4) Prestasi pegawai tidak diikuti dengan pemberian penghargaan (reward) dan umpan balik (feedback) yang disesuaikan dengan kinerja yang telah ditentukan, terlihat dari tidak adanya pemberian insentif terhadap pegawai yang memiliki kinerja tinggi di atas yang sudah ditetapkan.

5) Recruitment pegawai yang tidak memiliki kemampuan dan keterampilan yang sesuai dengan kebutuhan organisasi, termasuk dalam melakukan seleksi dan penempatannya.

6) Masih rendahnya kualitas sumber daya manusia, karena latar belakang pendidikan yang kurang berkualitas, terbatasnya kemampuan menganalisa dan tidak adanya standar kompetensi untuk tiap-tiap jenis pekerjaan dengan kemampuan pegawai yang ada (hasil wawancara dengan pejabat eselon IV, III dan W I).

7) Terdapat beberapa ciri atau karakter pegawai yang sukar untuk bekerja sama dengan orang lain dalam suatu kelompok pekerjaan (team work). Konsep Learning organization memerlukan adanya suatu kerja sama tim yang berjalan dengan baik.

8) Kebanyakan pegawai telah terpola pemikirannya (mindset) untuk tidak melakukan perubahan yang berarti untuk organisasi. Mereka bekerja setiap hari (rutin) hanya untuk menjalankan kewajiban semata, tidak melihat tuntutan lingkungan untuk berkinerja lebih baik dalam memberikan pelayanan kepada stakeholders (hasil observasi dan wawancara dengan pejabat eselon III, IV dan W 1).

9) Karakteristik individu yang terlalu cepat puas dengan keadaan yang ada (Comfort Zone) atau resisten terhadap perubahan, menyebabkan sebagian besar dari mereka sulit termotivasi untuk menemukan inovasi baru untuk kepentingan perubahan yang dibutuhkan organisasi dalam menghadapi perubahan dan tujuan organisasi.

10) Budaya belajar belum dimiliki setiap pegawai, sedangkan learning organization memberikan petunjuk bahwa budaya belajar individu sangatlah penting bagi organisasi dalam mengantisipasi perubahan yang semakin cepat dan global (hasil wawancara dengan eselon IV, III dan W 1).

Berdasarkan kendala-kendala yang dihadapi pada organisasi, menunjukan bahwa para pegawai yang ada di organisasi belum sepenuhnya melaksanakan pembelajaran tanpa henti untuk memperluas kapasitasnya guna mencapai basil yang betul-betul dikehendaki. Budaya belajar terus menerus secara bersama guna meraih kepentingan dan tujuan bersama belum terwujud 
sepenuhnya. Hal ini menunjukkan bahwa learning organization belum sepenuhnya diterapkan di PPSDMAP. Padahal di sisi yang lain PPSDMAP diharapkan dapat melaksanakan dalam mengembangkan sumber daya manusia transportasi yang handal melakukan proses pembelajaran kolektif secara terus menerus guna mentransformasi organisasi tersebut dengan cara yang lebih baik dalam rnengumpulkan, mengelola dan memanfaatkan pengetahuan bagi keberhasilan organisasi. Untuk dapat menjalankan fungsi tersebut, perlu dimulai dari PPSDMAP itu sendiri (baik individu ataupun organisasi) yang harus terus melakukan proses pembelajaran guna mengembangkan kompetensi individu dan guna penyesuaian terhadap perubahan yang terjadi baik di dalam organisasi ataupun di tuar organisasi, serta harus mempersiapkan diri melalui konsep pengembangan sum berdaya manusia dengan organisasi masa depan melalui organisasi pembelajaran yaitu organisasi yang senantiasa belajar dan memecahkan masalah secara bersamasama. Sesuatu hal yang perlu dilakukannya adalah mempersiapkan sumber daya manusia secara terus-menerus melalui proses belajar.

Sebelum diterapkan dan dikembangkannya learning organization itu, perlu dilakukan terlebih dahulu pemetaan potensi dari setiap sub- sistem dari learning organization di PPSDMAP Pemetaan ini sangat perlu dilakukan terlebih dahulu, guna mengetahui potensi dari setiap sub-sistem dari learning organization dan dapat diperoleh strategi yang tepat untuk dapat menerapkan learning organization di PPSDAM.

\section{KESIMPULAN}

1) Secara analitik, dari seluruh penilaian subsistem organisasi pembelajar menunjukan bahwa PPSDMAP mempunyai potensi menuju Corporate University. Hal ini tampak dari kelima subsistem organisasi pembelajar yang diteliti memiliki nilai rata-rata dalam kategori baik (range result menurut Michael J. Marquardt bahwa nilai rata-rata 25-32 adalah good atau baik), yaitu:

a. Subsistem Dinamika Pembelajaran dengan nilai rata-rata sebesar 27,97 dapat menunjang terbangunnya learning organization dilihat dari individual learning dan team learning.

b. Subsistem Transformasi Organisasi dengan nilai rata-rata 27,57 merupakan dukungan penerapan learning organization terkait dengan visi, budaya, dan struktur organisasi.

c. Subsistem Pemberdayaan Sumber Daya Manusia mendapat nilai rata-rata paling tinggi diantara keempat subsistem lainnya yaotu 28,5. Artinya, terdapat dukungan dari factor sumber daya manusia baik employee empowerment, leader empowerment, public empowerment, dan partnership empowerment.

d. Subsistem Pengelolaan Pengetahuan dengan nilai rata-rata 26,83 untuk knowledge acquisition, knowledge creation, knowledge storage, dan knowledge transfer.

e. Subsistem Penerapan Teknologi nilai rata-rata sebesar 26,37 dan merupakan nilai rata-rata terendah dari subsistem lainnya mencakup system informasi pengetahuan, pembelajaran berbasis teknologi, dan sistem elektronik berbasis kinerja.

Peta potensi untuk keseluruhan subsistem dari learning organization tergolong belum kuat untuk dapat dibangunnya organisasi pembelajaran. Karena nilai rata-rata masih berada di bawah nilai 33 (dibawah nilai excellent atau sempurna yang direkomendasikan Marquardt), yang artinya masih bnayak usaha atau perbaikan yang harus dilakukan guna terbangunnya learning organization. Hal yang terpenting untuk dapat menerapkan learning organization itu harus ada komitmen terlebih dahulu terutama dari pimpinan untuk penerapannya. 
2) Tantangan dan kendala PPSDMAP menuju Corporate University ditinjau dari :

a. Dinamika pembelajaran organisasi dan proses transformasi budaya organisasi menuju organisasi professional cenderung lambat dan didominasi kultur birokratis (highly bureaticratie).

b. Pemberdayaan SDM belum dikelola secara optimal dan transparan berdasarkan merit system dan belum linier dengan kebijakan pengembangan kompetensi.

c. Pengelolaan pengetahuan pada 'PPSDMAP belum dikelola secara sistematis, mulai dari perolehan, pembentukan, penyimpanan, diseminasi dan penerapan pengetahuan.

d. Penerapan teknologi pada PPSDMAP telah dilakukan dan dalam bentuk yang terbatas seperti belum adanya learning management system (LAN) sehingga proses pembelajaran belum optimal.

\section{Saran}

1) Membangun komitmen yang kuat dijajaran pimpinan PPSDMAP untuk memberdayakan seluruh subsistem yang dimiliki (Pembelajaran, Organisasi, SDM, Pengetahuan dan Teknologi) yang disertai dengan kebijakan untuk menjadi organisasi pembelajar.

2) Perlu dilakukan pemberdayaan SDM (employee empowerment), khususnya terkait dengan pendelegasian tugas sesuai dengan kualifikasi dan kompetensinya, serta pengelolaan pengetahuan perlu dibuat dengan sistem dan terstruktur.

3) Penerapan pola pembelajaran PPSDMAP menuju Corporate University dapat dilaksanakan secara bertahap, dimulai dari penerapan teknologi berupa pembelajaran rnelalui e-learning dan blended learning dan penyiapan Learning Management System (LMS). Sebagai langkah awal, perlu dilakukan persiapan grand design PPSDMAP menuju Corporate University yang memuat lima subsistem organisasi pembelajar, dan membuat panduan atau buku pedoman tentang persiapan dan langkah-langkah PPSDMAP menuju Corporate University.

\section{DAFTAR PUSTAKA}

Allen, M. (2002). The corporate university handbook: Designing, managing, and growing a successful program. Amacom Books.

Ayuningtias, H. G., Nurbaiti, A., Anggadwita, G., \& Putri, M. K. (2016). The corporate university landscape in Indonesia. 3rd International Seminar and Conference on Learning Organization.

Balitbangkumham. (2019). Meniti Strategi Corporate University Refleksi Kemenkumham sebagai Organisasi Pembelajar. Policy Paper, Vol 1 No.

Citrawan, H., Swastika, N., Firdaus;, Primawardani, Y.; Situmorang, V. H. A. ., \& Abdillah, J. (2019). Meniti Strategi Corporate University Refleksi Kemenkumham sebagai Organisasi Pembelajar. In POLICY PAPER BALITBANGKUMHAM Vol.1 no. 1. BALITBANGKUMHAM Press (Anggota IKAPI).

Firdaus, A. (2017). The Implementation of Corporate University in Public Sector: Case Study Ministry of Finance of Indonesia. Institute of Social Studies. The Hague, The Netherland.

Keuangan, K., Pendidikan, B., \& Keuangan, P. (2016). Kemenkeu Corporate University: Belajar Tanpa Batas, Kinerja Berkualitas. Rapat Koordinasi BPPK.

Lembaga Administrasi Negara. (2018). "Menuju Birokrasi Kelas Dunia, Kemenpan Rb dan LAN Siapkan ASN Corporate University. http://lan.go.id/Id/Berita-Lan/Menuju-Bi-rokrasiKelas-Dunia-Kemenpan-rb-dan-Lan-Siapkan-Asn-Corpo-rate-University 
Marquardt, M. J. (2002). Building the learning organization: Mastering the 5 elements for corporate learning. Nicholas brealey publishing.

Marquardt, M. J., Marquardt, M., \& Reynolds, A. (1994). The global learning organization. Irwin Professional Pub.

Martyn F. Rademakers. (n.d.). Corporate University Merancang, Membangun dan Mengelola Organisasi Pembelajar, PPM Jakarta, 2020.

Senge, P. M. (1995). Learning organizations. Gilmour Drummond Publishing Cambridge.

Sugiarsono, J., Djawahir, K., \& Musthafa, B. (n.d.). What You Should Know About Corporate University PLN Corporate University 2019. 